\title{
Feeding Sprague Dawley Rats With Jordanian Wild Edible Plants and a High Fat Diet Reduced the Malondialdehyde Levels
}

\author{
Anwar A. Al-Assaff ${ }^{1} \&$ Hamed R. Takruri ${ }^{1}$ \\ ${ }^{1}$ Department of Nutrition and Food Technology, School of Agriculture, The University of Jordan, Amman, \\ Jordan \\ Correspondence: Hamed R. Takruri, Department of Nutrition and Food Technology, School of Agriculture, The \\ University of Jordan, Amman, Jordan. E-mail: htakruri@ju.edu.jo
}

Received: April 13, 2019

doi:10.5539/jas.v11n10p71
Accepted: May 22, 2019 Online Published: July 15, 2019

URL: https://doi.org/10.5539/jas.v11n10p71

The research is financed by The University of Jordan.

\begin{abstract}
The objective of this study was to determine the effect of selected Jordanian wild edible plant on lipid peroxidation and lipid profile in adult male Sprague Dawley rats fed high-fat diet. Fiftysix male, adult Sprague-Dawley rats at eight weeks of age, weighing about $200 \mathrm{~g}$ were distributed into 7 experimental groups, 7 rats each. The groups included a negative control group that was fed a normal fat diet (NFD) and a possitve control group that was fed a high fat diet (HFD) (45\% calories from fat). The six treatment groups were fed a HFD for the first 4 weeks of the experiment and a HFD with $9 \%$ of one of the selected dried plants for another 4 weeks. The treatment groups are sumac, thyme, clary, gundelia, garden rocket and wild mint. Blood samples were collected from the right heart ventricle. Serum malondialdehyde, lipid profile and fasting blood glucose were measured for rats. Results showed that the addition of different dried plant powders to the HFD did not significantly affect serum levels of TG, TC, HDL, LDL and fasting blood glucose. On the other hand, malondialdehyde (MDA) levels were significantly $(\mathrm{p}<0.05)$ higher in the HFD group $(4.09 \pm 0.45 \mathrm{mmol} / \mathrm{ml})$ than those of other groups. MDA serum levels for the other groups were as follows: NFD (2.47 \pm 0.05$)$, sumac (2.45 \pm 0.13$)$, thyme $(2.88 \pm 0.07)$, clary $(2.97 \pm 0.16)$, garden rocket (2.96 \pm 0.11$)$, gundelia (2.92 \pm 0.16$)$ and wild mint (2.68 \pm 0.09$)$. These levels were not sinificantly different from each other. It is concluded that incorporating dried plant powders in rat diets had a significantly positive effect only on lipid peroxidation assay as indicated by serum MDA levels.
\end{abstract}

Keywords: antioxidants, wild edible plants, oxidative stress, malondialdehyde, high fat diet

\section{Introduction}

Oxidative stress could be defined as a state of imbalance between the production and neutralization of free radicals in the body (Kratchanova et al., 2014). It is a major factor for several degenerative and inflammatory diseases (Tawaha et al., 2007). Free radicals are atoms, molecules, or ions with unpaired electrons that are highly unstable and active toward chemical reactions with other molecules such as reactive oxygen species (ROS) (Lu et al., 2010). The main target molecules of ROS are nucleic acids, proteins, sugars and lipids (Craft et al., 2012).

The oxidation of polyunsaturated fatty acids (PUFAs) in biological systems by free-radicals is known as lipid peroxidation (Esterbauer \& Cheeseman, 1990). The main primary products of lipid peroxidation are lipid hydroperoxides (Ayala et al., 2014). Many different aldehydes can be formed as secondary products during lipid peroxidation such as malondialdehyde (MDA), propanal, hexanal, and 4-hydroxynonenal (4-HNE) (Ayala et al., 2014). MDA has been widely used for many years as a convenient biomarker for lipid peroxidation because of its reaction with thiobarbituric acid (TBA) (Esterbauer \& Cheeseman, 1990).

Antioxidants may be defined as compounds that can significantly delay or inhibit the oxidation process of lipid or other molecules and protect against free radicals by inhibiting the initiation or propagation of oxidizing chain reactions (Volf, 2014). Antioxidants are important in terms of their ability to protect against oxidative cell damage that can lead to several chronic diseases (Rajendran et al., 2014). Various types of antioxidants are present in the diet to maintain free radical concentrations at low levels (Carocho \& Ferreria, 2013). 
Dietary polyphenols are among the most important groups of natural antioxidants that are found in human diet. Epidemiological, clinical and nutritional studies strongly support the evidence that dietary phenolic compounds enhance human health by lowering risk and preventing the onset of degenerative diseases (Scalbert et al., 2005). Sumac, thyme, clary, garden rocket, gundelia and wild mint are among the sources of polyphenols that are consumed in Jordan.

Rhus coriaria L. belongs to Anacardiaceae family (Ali-Shtayeh et al., 2014; Al-Eiswi \& Takruri, 1989). Traditionally it has been used in the treatment of diarrhea, ulcer, hemorrhoids, liver disease, dysentery, diuresis, hemorrhage, hematemesis, hemoptysis, ophthalmia, conjunctivitis, leucorrhea, and as stomach tonic (Shabbir, 2012).

Thyme (Origanum syriacum L.) belongs to the Lamiaceae family (Husein et al., 2014; Al-Eiswi \& Takruri, 1989). It has been widely used in the traditional herbal medicine (Ayesh et al., 2014).Thyme is included in the list of The United States Food and Drug Administration (FDA) which contains more than 150 plants that present essential oils, oleoresins (solvent-free), and natural extractives (including distillates) that are safe for human consumption without limitations on intake (Costa et al., 2015).

Clary (Salvia Judaica Boiss.), also called Judean sage, is from Lamiaceae family (Al-Ismail et al., 2007; Al-Eiswi \& Takruri, 1989). In Jordan, it grows in different areas of the country and is collected to be stuffed with rice, meat, oil and spices, then it is cooked and used in the Jordanian diet (Tukan et al., 1998).

Garden rocket (Eruca sativa Mill.) is a member of the Cruciferae family (Ali-Shtayeh et al., 2014; Al-Eiswi \& Takruri, 1989). The leaves of this plant are traditionally used as antiscorbutic, diuretic, stimulant and stomachic. The rocket seeds oil also has glucosinolate methyl sulphinyl butyl isothiocyanate which induces enzymes activity (Gulfraz et al., 2011). The phenolic compounds in the seeds have antimicrobial properties against pathogenic bacteria while tannins are reported to have antiviral, antibacterial and antitumor activity (Khoobchandania et al., 2010).

Gundelia (Gundelia tournefortii L.) belongs to the Asteraceae (Compositae) family (Ali-Shtayeh et al., 2014; Al-Eiswi \& Takruri, 1989). Dry seeds of G.tournefortii are known to be effective for the treatment of vertigo disease, in Eastern Anatolia folk medicine (Evin, 2012). Fresh seeds of G. tournefortii are used in pickles and also are effective diuretics (Evin, 2012). Latex obtained from roots of G.tournefortii is used externally (Evin, 2012). In Jordan it is fried with egg or cooked with meat to be consumed in the Jordanian diet (Tukan et al., 1989).

Wild mint (Mentha longifolia (L.) Hudson) is a member of the large mint family Lamiaceae (Ali-Shtayeh et al., 2014; Al-Eiswi and Takruri, 1989). Milk or water decoctions of wild mint leaves were used traditionally for coughs, colds, asthma and other bronchial illnesses. It has also been used to treat headaches, fevers, indigestion, flatulence, hysteria, painful menstruation, delayed pregnancy and urinary tract infections (Viljoen et al., 2006).

Therefore, the objective of this study was to determine the antioxidant capacity of these plants by using malondialdehyde as an indicator.

\section{Materials and Method}

\subsection{Animals and Experiment Diets}

The research was approved by the ethics committee of the Department of Nutrition and Food Technology for Animal Experimentation/ The Univarsity of Jordan. Sixty four adult male Sprague Dawley rats, weighing around $200 \mathrm{~g}$ were divided into 8 groups; negative control (G1), positive control (G2) and six treatment groups (G3, G4, G5, G6, G7, G8). The rats were housed individually in plastic cages with wire mesh and a plastic tray underneath under controlled conditions of: temperature $\left(22 \pm 2{ }^{\circ} \mathrm{C}\right)$, relative humidity $(49 \pm 5 \%)$ and hygienic conditions in ventilated room and a 12-12 hours' light- dark cycle. The animals were acclimatized for one week during which they were fed standard chow and tap water ad libitum. Weight gain and food consumption were monitored weekly.

The experimental diet mixtures were prepared according to the guidelines of American Institute of Nutrition 1993 for adult animals (AIN-93M) (Reeves, 1997). These diet mixtures used in the experiment were as follows; standard AIN-93M diet; high fat diet (HFD) which was a modified AIN-93M diet for the fat ( $45 \%$ of the calories from fat); HFD with $9 \%$ sumac; HFD with $9 \%$ thyme powder; HFD with $9 \%$ clary powder; HFD with $9 \%$ garden rocket powder; HFD with 9\% gundelia powder and HFD with $9 \%$ wild mint powder. The plants powders were obtained by sun-drying of the fresh plants, grinding them using a domestic coffee mill. The composition of the diet mixtures is shown in Table 1. 
G1 received standard AIN-93M diet for the 8 weeks period and G2 was fed HFD for the 8 weeks period while G3, G4, G5, G6, G7 and G8 were fed HFD for the first 4 weeks followed by HFD with 9\% plant powder for another 4 weeks. Weight gain and food consumption were monitored weekly. At the end of the experiment, the rats were sacrificed and blood samples were collected, after 8 hours fasting by cardiac puncher, in plain separate gel tubes. Then the samples were centrifuged at $3000 \mathrm{rpm}$ for 10 minutes (HERMLE Z200A centrifuge, Labor Technik, Wehingen, Germany). Finally serum samples were stored at $-18{ }^{\circ} \mathrm{C}$ until analysis.

Table 1. Experimental diets composition

\begin{tabular}{|c|c|c|c|c|c|c|c|c|}
\hline Ingredient & Normal diet & HFD & Sumac & Thyme & Garden rocket & Clary & Gundelia & Wild mint \\
\hline Corn starch (g) & 612.5 & 341.7 & 277.7 & 302.4 & 304.4 & 308.2 & 297.8 & 307.4 \\
\hline Egg white (g) & 140 & 172.5 & 170.3 & 159.7 & 162.1 & 160.1 & 166.2 & 158.2 \\
\hline Sucrose (g) & 100 & 125 & 125 & 125 & 125 & 125 & 125 & 125 \\
\hline Fiber(g) & 40 & 64.9 & 55.5 & 50.9 & 50.2 & 52 & 53.3 & 48.2 \\
\hline Soybean oil (g) & 40 & 50 & 43.5 & 46.5 & 48.3 & 48.2 & 48.5 & 47.8 \\
\hline Sheep tallow (g) & - & 187.9 & 187.9 & 187.9 & 187.9 & 187.9 & 187.9 & 187.9 \\
\hline Choline (g) & 2.5 & 3 & 3 & 3 & 3 & 3 & 3 & 3 \\
\hline Vitamin mix (g) & 10 & 10 & 10 & 10 & 10 & 10 & 10 & 10 \\
\hline Mineral mix (g) & 35 & 35 & 35 & 35 & 35 & 35 & 35 & 35 \\
\hline Biotin $_{\text {premix }}(\mathrm{g})$ & 10 & 10 & 10 & 10 & 10 & 10 & 10 & 10 \\
\hline $\mathrm{TBHQ}_{2}(\mathrm{mg})$ & 8 & 47.58 & 47.58 & 47.58 & 47.58 & 47.58 & 47.58 & 47.58 \\
\hline Plant (g) & - & - & 90 & 90 & 90 & 90 & 90 & 90 \\
\hline Total (g) & 1000 & 1000 & 1008.06 & 1020.35 & 1025.84 & 1029.47 & 1026.71 & 1022.40 \\
\hline $\mathrm{Kcal} / \mathrm{g}_{3}$ & 3.8 & 4.7 & 4.7 & 4.6 & 4.6 & 4.6 & 4.6 & 4.6 \\
\hline
\end{tabular}

Note. Biotin pre-mix composed of $130 \mathrm{mg}$ of biotin with $999.87 \mathrm{~g}$ of corn starch. TBHQ: tertiary butylhydroquinone; Kcal/g: kilo calorie per gram diet.

\subsection{Lipid Peroxidation Assay}

Serum malondialdehyde (MDA) was determined according to thiobarbituric reactive substance assay (TBARS) described by Esterbabuer and Cheeseman, (1990) which is based on the reaction of MDA with thiobarbituric acid (TBA) producing a pink pigment.

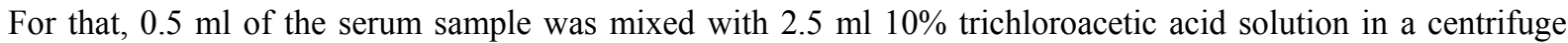
tube, then the tube was placed in a boiling water bath for $15 \mathrm{~min}$. After that it was cooled in cold water and centrifuged at $3000 \mathrm{rpm}$ for 5 min using (HERMLE Z200A centrifuge, Labor Technik, Wehingen, Germany). Then $2 \mathrm{ml}$ of the supernatant was added to $1 \mathrm{ml}$ of $0.67 \%$ TBA solution in a test tube and placed in a boiling water bath for another $15 \mathrm{~min}$ and finally cooled in tap water. The absorbance was measured at $532 \mathrm{~nm}$ using UV/Visible spectrophotometer (Lambda 3b, PERKIN ELMER, USA) against a sample blank of distilled water.

Serum lipids and fasting blood glucose were measured in a Medical Laboratory (Mega Lab, Amman, Jordan). An automated clinical analyzer (Mindray BS 380, China) was used for the analysis.

\subsection{Statistical Analysis}

Statistical analysis of the data was performed using the Statistical Package for the Social Sciences (SPSS) version 19. Analysis of variance (ANOVA) along with LSD test were used to determine any significant differences among the variable means of the experimental groups. The data was presented as mean \pm SEM. $\mathrm{P}$ value of less than 0.05 was considered significant.

\section{Results}

\subsection{Weight Gain, Food Intake and Food Efficiency Ratio (FER)}

Table 2 shows the mean initial and final body weights, weight gain, accumulative food intake and food efficiency ratio for the groups. Initial body weights among the different groups were close to each other with no significant differences. Final body weight values among experimental groups were also not significantly different from each other $(\mathrm{p}>0.05)$. For weight gain, it also was not significantly different among the studied groups $(p>0.05)$. Accumulative food intake (g) of NFD group (1096.47 \pm 118.6$)$ was significantly higher than that of the other experimental groups $(\mathrm{p}<0.05)$, while there were no significant differences among the other 
groups. Regarding food efficiency ratio $(\mathrm{g} / 100 \mathrm{~g})$, there were no differences among the studied groups ( $\mathrm{p}>$ $0.05)$.

Table 2. Initial and final body weights, body weight gain, accumulative food intake and food efficiency ratio among experimental groups for eight weeks*

\begin{tabular}{|c|c|c|c|c|c|}
\hline Group (Diet) & Initial weight $(\mathrm{g})^{* *}$ & Final weight (g) & Weight gain (g) & $\begin{array}{l}\text { Accumulative food } \\
\text { intake (g) }\end{array}$ & $\begin{array}{l}\text { Food efficiency } \\
\text { ratio }(g / 100 g) * * *\end{array}$ \\
\hline G1 (NFD) & $195.03 \pm 7.11^{\mathrm{a}}$ & $355.64 \pm 12.70^{\mathrm{a}}$ & $160.61 \pm 6.84^{\mathrm{a}}$ & $1096.47 \pm 44.82^{\mathrm{a}}$ & $14.65 \pm 0.76^{\mathrm{a}}$ \\
\hline G2 (HFD) & $202.44 \pm 8.65^{\mathrm{a}}$ & $338.97 \pm 16.03^{\mathrm{a}}$ & $136.53 \pm 14.16^{\mathrm{a}}$ & $869.01 \pm 25.56^{\mathrm{b}}$ & $15.71 \pm 1.56^{\mathrm{a}}$ \\
\hline G3 $\left(\right.$ Sumac) ${ }^{\dagger}$ & $197.63 \pm 8.34^{\mathrm{a}}$ & $323.29 \pm 16.81^{\mathrm{a}}$ & $125.66 \pm 11.66^{\mathrm{a}}$ & $844.94 \pm 48.17^{\mathrm{b}}$ & $14.96 \pm 1.34^{\mathrm{a}}$ \\
\hline G4 (Thyme) ${ }^{\dagger}$ & $197.70 \pm 4.68^{\mathrm{a}}$ & $331.71 \pm 8.08^{\mathrm{a}}$ & $134.01 \pm 9.10^{\mathrm{a}}$ & $879.94 \pm 25.21^{b}$ & $15.25 \pm 1.00^{\mathrm{a}}$ \\
\hline G5 (Clary) $^{\dagger}$ & $196.94 \pm 4.82^{\mathrm{a}}$ & $328.57 \pm 7.94^{\mathrm{a}}$ & $131.63 \pm 8.08^{\mathrm{a}}$ & $841.51 \pm 31.90^{\mathrm{b}}$ & $15.70 \pm 0.95^{\mathrm{a}}$ \\
\hline G6 (Garden rocket) ${ }^{\dagger}$ & $201.10 \pm 5.62^{\mathrm{a}}$ & $356.47 \pm 7.70^{\mathrm{a}}$ & $155.37 \pm 10.30^{\mathrm{a}}$ & $905.93 \pm 31.93^{b}$ & $17.34 \pm 1.43^{\mathrm{a}}$ \\
\hline G7 (Gundelia) ${ }^{\dagger}$ & $196.40 \pm 9.56^{\mathrm{a}}$ & $345.16 \pm 9.68^{\mathrm{a}}$ & $148.76 \pm 13.30^{\mathrm{a}}$ & $912.06 \pm 32.04^{\mathrm{b}}$ & $16.34 \pm 1.50^{\mathrm{a}}$ \\
\hline G8 (Wild mint) ${ }^{\dagger}$ & $201.56 \pm 6.28^{\mathrm{a}}$ & $348.64 \pm 14.96^{\mathrm{a}}$ & $147.09 \pm 11.34^{\mathrm{a}}$ & $887.83 \pm 26.82^{b}$ & $16.62 \pm 1.26^{\mathrm{a}}$ \\
\hline
\end{tabular}

Note. NFD: normal fat diet; HFD: high fat diet. * Values are presented as mean \pm SEM. Different superscript letters in the same column indicate significant difference at $p<0.05$; $* *$ Initial body weight was measured after one week acclimatization; *** Food efficiency ratio = body weight gain $(\mathrm{g}) / 100 \mathrm{~g}$ food intake; High fat diet: $45 \%$ of calories from fat; ${ }^{\dagger}$ Dried plants comprise $9 \%$ of the $\operatorname{diet}(90 \mathrm{~g} / \mathrm{kg} \mathrm{diet})$.

\subsection{Serum Glucose, Lipid Profile and Lipid Peroxidation Assay}

Table 3 shows the lipid profile, serum glucose and lipid peroxidation assay for rats blood serum among different experimental groups at the end of the experiment.

Garden rocket group had the lowest fasting glucose value (163.83 \pm 13.92$)$ followed by gundelia group (164.17 \pm 21.28$)$, sumac group (166.00 \pm 4.95$)$, clary group (169.33 \pm 9.37$)$, wild mint group (170.00 \pm 9.47$)$, NFD group (174.17 \pm 17.22$)$, thyme group $(174.50 \pm 4.43)$ and finally HFD group which had the highest fasting glucose value $(176.50 \pm 17.67)$. However, There were no significant differences in serum fasting glucose (mg/dL) among all of the studied groups $(\mathrm{p}>0.05)$.

Regarding TG levels $(\mathrm{mg} / \mathrm{dL})$, there were no differences among the groups $(\mathrm{p}>0.05)$. The values were ranged from $(113.60 \pm 19.24)$ for the clary group to $(150.83 \pm 54.99)$ for the gundelia group. Also, there were no significant differences in TC serum levels (mg/dL) among the groups. TC values were ranged from (64.33 \pm 7.97$)$ for the clary group to $(79.25 \pm 10.69)$ for NFD group.

Similarly, serum levels of HDL (mg/dL) for different experimental groups were close to each other, with no significant differences among them $(\mathrm{p}>0.05)$. HDL levels were ranged from $(45.86 \pm 3.98)$ for NFD group to $(49.71 \pm 7.05)$ for the thyme group. For LDL levels $(\mathrm{mg} / \mathrm{dL})$, there were no significant differences among the groups. The values of LDL were ranged from (5.93 \pm 4.12$)$ for thyme group to (13.90 \pm 1.41$)$ for HFD group.

However, MDA concentration (nmol/mL) of HFD group (4.09 \pm 0.45$)$ was significantly higher than that of the other experimental groups. MDA concentrations of sumac group (2.45 \pm 0.13$)$, NFD group (2.47 \pm 0.15$)$, wild mint group (2.68 \pm 0.23$)$, thyme group (2.88 \pm 0.18 ), clary group (2.97 \pm 0.43$)$, garden rocket group (2.96 \pm 0.29$)$ and gundelia group $(2.92 \pm 0.43)$ were close to each other, with no significant differences among them $(\mathrm{p}>0.05)$. 
Table 3. Biochemical analysis for rats fed different experimental diets for eight weeks *

\begin{tabular}{|c|c|c|c|c|c|c|}
\hline \multirow{2}{*}{ Group } & \multirow{2}{*}{ Blood glucose $(\mathrm{mg} / \mathrm{dL})$} & \multicolumn{4}{|c|}{ Blood Lipids (mg/dL) } & \multirow{2}{*}{ MDA (nmol/ml) } \\
\hline & & TG & TC & HDL & LDL & \\
\hline G1 & $174.17 \pm 7.03^{\mathrm{a}}$ & $127.40 \pm 4.41^{\mathrm{a}}$ & $79.25 \pm 4.04^{\mathrm{a}}$ & $46.00 \pm 1.96^{\mathrm{a}}$ & $9.65 \pm 1.70^{\mathrm{a}}$ & $2.47 \pm 0.05^{b}$ \\
\hline $\mathrm{G} 2$ & $176.50 \pm 7.22^{\mathrm{a}}$ & $133.83 \pm 25.41^{\mathrm{a}}$ & $72.00 \pm 4.21^{\mathrm{a}}$ & $48.00 \pm 2.66^{\mathrm{a}}$ & $13.90 \pm 0.58^{\mathrm{a}}$ & $4.09 \pm 0.17^{\mathrm{a}}$ \\
\hline G3 & $166.00 \pm 4.95^{\mathrm{a}}$ & $116.40 \pm 6.04^{\mathrm{a}}$ & $65.00 \pm 3.48^{\mathrm{a}}$ & $47.17 \pm 2.51^{\mathrm{a}}$ & $8.75 \pm 1.95^{\mathrm{a}}$ & $2.45 \pm 0.13^{\mathrm{b}}$ \\
\hline G4 & $174.50 \pm 2.22^{\mathrm{a}}$ & $141.33 \pm 21.88^{\mathrm{a}}$ & $72.17 \pm 4.99^{\mathrm{a}}$ & $49.71 \pm 2.68^{\mathrm{a}}$ & $5.93 \pm 1.68^{\mathrm{a}}$ & $2.88 \pm 0.07^{\mathrm{b}}$ \\
\hline G5 & $169.33 \pm 3.83^{\mathrm{a}}$ & $113.60 \pm 8.61^{\mathrm{a}}$ & $64.33 \pm 3.25^{\mathrm{a}}$ & $46.71 \pm 1.74^{\mathrm{a}}$ & $10.23 \pm 2.84^{\mathrm{a}}$ & $2.97 \pm 0.16^{\mathrm{b}}$ \\
\hline G6 & $163.83 \pm 5.68^{\mathrm{a}}$ & $130.14 \pm 11.76^{\mathrm{a}}$ & $70.14 \pm 1.57^{\mathrm{a}}$ & $45.86 \pm 1.50^{\mathrm{a}}$ & $8.22 \pm 1.01^{\mathrm{a}}$ & $2.96 \pm 0.11^{\mathrm{b}}$ \\
\hline G7 & $164.17 \pm 8.69^{\mathrm{a}}$ & $150.93 \pm 22.45^{\mathrm{a}}$ & $68.67 \pm 4.20^{\mathrm{a}}$ & $48.14 \pm 2.33^{\mathrm{a}}$ & $9.04 \pm 1.81^{\mathrm{a}}$ & $2.92 \pm 0.16^{\mathrm{b}}$ \\
\hline G8 & $170.00 \pm 3.86^{\mathrm{a}}$ & $138.67 \pm 7.27^{\mathrm{a}}$ & $73.50 \pm 4.09^{\mathrm{a}}$ & $47.29 \pm 2.68^{\mathrm{a}}$ & $12.96 \pm 2.93^{\mathrm{a}}$ & $2.68 \pm 0.09^{b}$ \\
\hline
\end{tabular}

Note. G1: normal fat diet group (negative control); G2: high fat diet group (positive control); G3: sumac group; G4: thyme group; G5: clary group; G6: Garden rocket group; G7: Gundelia group; G8: wild mint group; NFD: normal fat diet; HFD: high fat diet; MDA: malondialdehyde. * Values are represented as mean \pm SEM. Different superscript letters in the same column indicate significant difference at $p<0$.

\section{Discussion}

Dyslipidemia refers to disruption of lipid metabolism which is characterized by increased LDL and triglyceride serum concentrations that are often accompanied by decreased HDL levels (Wazaify et al., 2013). Oxidative stress and ROS is closely associated with dyslipidemia and the formation of oxidized LDL which stimulates the release of more ROS and promotes platelet formation (Singh et al., 2015). ROS also could oxidize lipids leading to the formation of MDA (final product of lipid peroxidation) which is known to be a marker of oxidative damage (Ayala et al., 2014).

Wild edible plants are considered as a source of bioactive components and natural antioxidants which may contribute to the reduction of oxidative stress (Romojaro et al., 2013). Therefore, the objective of the present study was to evaluate the effect of selected local wild edible plants on lipid peroxidation and lipid profile in adult male Sprague Dawley rats.

Body weight changes can be used to evaluate nutrient utilization. As presented in Table 2, there were no significant differences among all experimental groups in either initial body weight, final body weight or body weight gain $(p<0.05)$. Even when using HFD there were no differences among the groups which is inconsistent with the findings of An et al. (2011) who found that weight gain of HFD group (65\% of calories from fat) was significantly higher than NFD. Also, Lee and others have concluded that weight gain of HFD group $(\sim 50 \%$ of calories from fat) was significantly higher than NFD group (Lee et al., 2006).

However, in another study Moraes et al. (2012) found that after introducing HFD containing ( $40 \%$ of calories from fat) to the animals there were no differences in body weight gain and final body weight (Moraes et al., 2012). Such a result is expected since total caloric intakes of groups were similar (approximately $4000 \mathrm{kcal}$ ).

To the best of our knowledge, there were no studies to determine the effect of any of the studied plants on body weight or weight gain in rats. However, Wang et al. (2014) showed that excessive weight gain and obesity could be prevented or slightly reversed by the intake of dietary polyphenols. This finding cannot be clearly observed in the present study since the positive control group was not significantly different from negative control group.

Accumulative food intake could be an indicator of the acceptability and palatability of food. According to results of this study accumulative food intake of NFD was significantly higher than other groups. It was reported in many studies that accumulative food intake of the group that received a standard diet was significantly higher than that of the groups which received HFD (Moraes et al., 2012; An et al., 2011; Lee et al., 2006).

In the present study, the values of fasting blood glucose among experimental groups were close to each other $(\mathrm{p}>0.05)$ (Table 3). Feeding HFD did not raise fasting blood glucose levels in comparison with feeding NFD which is consistence with the work of Moraes et al. (2012) and An et al. (2011). However, it has been reported that HFD in general can activate Toll-like receptors resulting in an immune response that promotes the activation of pro-inflammatory pathways leading to insulin resistance (Pfluger et al., 2008).

Serum lipids are used as an indicator for cardiovascular diseases. In this study, it was observed that HFD did not affect any parameter of blood lipids including TG, TC, HDL and LDL (Table 3). This result was consistent with what was observed by An et al. (2011) and Moraes et al. (2012). Lee and coworkers who used $\sim 50 \%$ of calories 
from fat obtained similar results regarding blood lipids except for HDL which was significantly higher in HFD group than NFD group (Lee et al., 2006). There are several possible reasons for this result. Firstly, the time period may have been insufficient to induce dyslipidemia. Furthermore, food intake of the HFD was lower than that of NFD (Table 2); thus it needs more time to show an effect. In addition, the amount and type of fat used may have a role in affecting blood lipids. On the other hand, other studies indicated that rats which received HFD have significantly higher TG, TC and LDL than those that received standard diet (Karam et al., 2016; Guo et al., 2011).

The addition of different plants to the HFD did not result in significant effect on blood lipids although it was expected that the addition of the plants may have a protective effect against dyslipidemia. This observation may be explained by the possibility that the four weeks period (first four weeks of the experiment) was not sufficient to produce hyperlipidemia at the beginning of the experiment and that the last four weeks period of the experiment may had not been enough to exhibit a significant effect on blood lipids.

Moreover, introducing the plants into the diet at the middle of the experiment and not from the beginning could elucidate such an observation. Besides that, the bioavailability of phenolic compounds could be a problem since it is absorbed in very little amounts and its concentration in the plasma and tissues was very low too (Cartea et al., 2010). It is reported that cell wall-bound phenolic compounds differ from those of free phenolic compounds in terms of bioavailability (Cartea et al., 2010). In addition to that sun drying was found to decrease polyphenols content as a result of increased enzyme activity (Kamiloglu et al., 2016).

Ingesting HFD increases the oxidative stress and ROS production in the body (Nappo et al., 2002). Lipids are considered as a target for ROS which oxidize it in a process called lipid peroxidation (Ayala et al., 2014). Malondialdehyde (MDA) is a secondary product of lipid peroxidation process and it can be measured by TBARS assay (Ayala et al., 2014; Esterbauer \& Cheeseman, 1990). In this study serum MDA was measured as an indicator of lipid peroxidation which reflects the degree of antioxidant capacity in vivo. Based on what we found in the present study (Table 3), all of the tested plants were found to decrease the serum levels of MDA compared with HFD group.

Up to our knowledge, no researchers have investigated the antioxidant capacity of the tested plants by measuring MDA serum concentration in rats fed HFD. However, some studies reported the protective effect of some of the plants or its extracts against oxidative stress induced by different ways in animals and humans.

Results from Candan and Sökmen study suggest that the methanolic extracts of sumac fruits have considerable antioxidant activity against lipid peroxidation process in vitro (Candan \& Sökmen, 2004). Salimi et al. (2015) studied the antioxidant effect of sumac aqueous extract in diabetic rats. Their results showed that MDA levels of the liver and kidney in diabetic animals treated with the extract were found to be lower than the non-treated diabetic group. Another study conducted by Pourahmad et al. (2010) investigated the hepatoprotective activity of aqueous extract of sumac and found that it is effective in lowering lipid peroxidation in liver cells indicated by MDA concentrations along with other oxidative stress biomarkers.

According to Viuda-Martos and others, thyme was found to prevent peroxidation of lipids in vitro (Viuda-Martos et al., 2010). Thyme powder, extract and oil were found to reduce liver MDA levels in rats with $\mathrm{CCl}_{4}$ induced liver injury (Al-Badr, 2011). Wild mint extract (500 mg/kg/day) was proven to decrease MDA serum levels in rats with acetic acid-induced colitis (Murad et al., 2016).

Seham et al. (2015) found that garden rocket oil lowered plasma MDA levels in rats on hypercholestrolic diet. In another study, liver MDA levels were lower in rats treated with ethanol, ethyl acetate and n-butanol gundelia extracts at doses of 200 and $300 \mathrm{mg} / \mathrm{kg}$ in comparison with the positive control rats with $\mathrm{CCl}_{4}$ induced liver damage (Niknahad et al., 2016). Unfortunately, there were no studies to compare the effect of clary on lipid peroxidation using MDA as an indicator in vivo or in vitro. In this study, clary was found to significantly lower serum MDA levels (Table 3).

The antioxidant effect of phenolic compounds is mainly due to their redox properties and their capacity to block the production of ROS. There are various possible mechanisms of this including: free radical scavenging activity, transition-metal-chelating activity, and/or singlet-oxygen-quenching capacity (Rubio et al., 2013).

A few limitations should be noted in this study. The duration of the animal experiment and the fat content in the diet possibly were not enough to produce dyslipidemia in the animals. In addition, using the dried plant powder which contains cell wall-bound phenolic compounds decreases their bioavailability. Furthermore, other biochemical tests could be used to evaluate oxidative stress in the body rather than using serum MDA only. 


\section{Conclusions}

Incorporating dried plant powders in rats diet did not significantly affect serum fasting glucose and lipid profile. However, its positive effect was observed only on lipid peroxidation assay as indicated by serum MDA levels.

\section{Acknowledgements}

The authors would like to thank The Deanship of Academic Research and Quality Assurance in The University of Jordan for the financial support.

\section{References}

Al-Ismail, K., Herzallah, S. M., \& Rustom, A. S. (2007). Antioxidant activities of some edible wild mediteranean plants. Ital. J. Food. Sci., 19(3), 287-296.

Ali-Shtayeh, M. S., Jamous, R. M., \& Abu-Zeitoun, S. Y. (2014). BERC 2014 National list of Medicinal Plants in Palestine-West Bank and Gaza Strip. A report by Biodiversity and Environmental Research Center (BERC), Til, Nablus, Palestine.

An, H. M., Park, S. Y., Lee, D. K., Kim, J. R., Cha, M. K., Lee, S. W., \& Ha, N. J. (2011). Antiobesity and lipid-lowering effects of Bifidobacterium spp. in high fat diet-induced obese rats. Lipids. Health. Dis., 10(1), 116. https://doi.org/10.1186/1476-511X-10-116

Ayala, A., Muñoz, M. F., \& Argüelles, S. (2014). Lipid peroxidation: production, metabolism, and signaling mechanisms of malondialdehyde and 4-hydroxy-2-nonenal. Oxid. Med. Cell. Longev. https://doi.org/ $10.1155 / 2014 / 360438$

Ayesh, B. M., Abed, A. A., \& Doa'a, M. F. (2014). In vitro inhibition of human leukemia THP-1 cells by Origanum syriacum L. and Thymus vulgaris L. extracts. BMC Research Notes., 7(1), 612. https://doi.org/ $10.1186 / 1756-0500-7-612$

Candan, F., \& Sökmen, A. (2004). Effects of Rhus coriaria L. (Anacardiaceae) on lipid peroxidation and free radical scavenging activity. Phytother. Res., 18(1), 84-86. https://doi.org/10.1002/ptr.1228

Carocho, M., \& Ferreira, I. C. (2013). A review on antioxidants, prooxidants and related controversy: Natural and synthetic compounds, screening and analysis methodologies and future perspectives. Food Chem. Toxicol., 51, 15-25. https://doi.org/10.1016/j.fct.2012.09.021

Cartea, M. E., Francisco, M., Soengas, P., \& Velasco, P. (2010). Phenolic compounds in Brassica vegetables. Molecules, 16(1), 251-280. https://doi.org/10.3390/molecules16010251

Costa, D. C., Costa, H. S., Albuquerque, T. G., Ramos, F., Castilho, M. C., \& Sanches-Silva, A. (2015), Advances in phenolic compounds analysis of aromatic plants and their potential applications. Trends Food Sci. Technol., 45(2), 336-354. https://doi.org/10.1016/j.tifs.2015.06.009

Craft, B. D., Kerrihard, A. L., Amarowicz, R., \& Pegg, R. B. (2012). Phenol - based antioxidants and the in vitro methods used for their assessment. Compr Rev. Food Sci. Food Saf., 11(2), 148-173. https://doi.org/ 10.1111/j.1541-4337.2011.00173.x

Esterbauer, H., \& Cheeseman, K. H. (1990). Determination of aldehydic lipid peroxidation products: Malonaldehyde and 4-hydroxynonenal. Methods Enzymol., 186, 407-421. https://doi.org/10.1016/ 0076-6879(90)86134-H

Evin, D. (2012). Thin layer drying kinetics of Gundelia tournefortii L. Food and Bioproducts Processing, 90(2), 323-332. https://doi.org/ 10.1016/j.fbp.2011.07.002

Gulfraz, M., Sadiq, A., Tariq, H., Imran, M., Qureshi, R., \& Zeenat, A. (2011). Phytochemical analysis and antibacterial activity of Eruca sativa seed. Pak. J. Bot., 43(2), 1351-1359.

Guo, F., Li, Y., Sun, C., Niu, Y., \& Feng, R. (2011). Effects of high-fat diet on blood lipids in rats. Journal of Hygiene Research, 40(1), 40-42.

Gutteridge, J. M. (1995). Lipid peroxidation and antioxidants as biomarkers of tissue damage. Clin. Chem., 4l(12), 1819-1828.

Husein, A. I., Ali-Shtayeh, M. S., Jamous, R. M., Zaitoun, S. Y. A., Jondi, W. J., \& Zatar, N. A. A. (2014). Antimicrobial activities of six plants used in Traditional Arabic Palestinian Herbal Medicine. Afr. J. Microbiol. Res., 8(38), 3501-3507. https://doi.org/10.5897/AJMR2014.6921 
Kamiloglu, S., Toydemir, G., Boyacioglu, D., Beekwilder, J., Hall, R. D., \& Capanoglu, E. (2016). A review on the effect of drying on antioxidant potential of fruits and vegetables. Critic. Rev. Food Sci. Nutr., 56(1), S110-S129. https://doi.org/10.1080/10408398.2015.1045969

Karam, I., Ma, N., Liu, X. W., Kong, X. J., Zhao, X. L., Yang, Y. J., \& Li, J. Y. (2016). Lowering effects of aspirin eugenol ester on blood lipids in rats with high fat diet. Lipids Health Dis., 15(1), 196. https://doi.org/10.1186/s12944-016-0369-2

Khoobchandani, M., Ojeswi, B. K., Ganesh, N., Srivastava, M. M., Gabbanini, S., Matera, R., \& Valgimigli, L. (2010). Antimicrobial properties and analytical profile of traditional Eruca sativa seed oil: Comparison with various aerial and root plant extracts. Food Chem., 120(1), 217-224. https://doi.org/10.1016/j.foodchem. 2009.10.011

Kratchanova, M. G., Denev, P. N., \& Kratchanov, C. G. (2014). Rose hip extract synergistically increase antioxidant activity of fruit and herb extracts. Bulg. Chem. Commun, 46, 59-64.

Lee, J. S., Lee, M. K., Ha, T. Y., Bok, S. H., Park, H. M., Jeong, K. S., \& Choi, M. S. (2006). Supplementation of whole persimmon leaf improves lipid profiles and suppresses body weight gain in rats fed high-fat diet. Food Chem. Toxicol., 44(11), 1875-1883. https://doi.org/10.1016/j.fct.2006.06.014

Lü, J. M., Lin, P. H., Yao, Q., \& Chen, C. (2010). Chemical and molecular mechanisms of antioxidants: Experimental approaches and model systems. J. Cell. Mol. Med., 14(4), 840-860. https://doi.org/10.1111/ j.1582-4934.2009.00897.x

Moraes, É. A., Natal, D. I. G., Queiroz, V. A. V., Schaffert, R. E., Cecon, P. R., de Paula, S. O., \& Martino, H. S. D. (2012). Sorghum genotype may reduce low-grade inflammatory response and oxidative stress and maintains jejunum morphology of rats fed a hyperlipidic diet. Food Res. Int., 49(1), 553-559. https://doi.org/10.1016/j.foodres.2012.07.029

Murad, H. A., Abdallah, H. M., \& Ali, S. S. (2016). Mentha longifolia protects against acetic-acid induced colitis in rats. J. Ethnopharmacol., 190, 354-361. https://doi.org/10.1016/j.jep.2016.06.016

Nappo, F., Esposito, K., Cioffi, M., Giugliano, G., Molinari, A. M., Paolisso, G., \& Giugliano, D. (2002). Postprandial endothelial activation in healthy subjects and in type 2 diabetic patients: Role of fat and carbohydrate meals. J. Am. CollCardiol., 39(7), 1145-1150. https://doi.org/10.1016/S0735-1097(02) 01741-2

Niknahad, H., Heidari, R., Mokhtebaz, T., Mansouri, S., Dehshahri, S., Abdoli, N., \& Najibi, A. (2016). Evaluating the effects of different fractions obtained from Gundelia tournefortii extract against carbon tetrachloride-induced liver injury in rats. Trends Pharmac. Sci., 2(1), 25-34.

Pfluger, P. T., Herranz, D., Velasco-Miguel, S., Serrano, M., \& Tschöp, M. H. (2008). Sirt1 protects against high-fat diet-induced metabolic damage. Proc Natl. Acad. Sci., 105(28), 9793-9798. https://doi.org/10.1073/ pnas.0802917105

Pourahmad, J., Eskandari, M. R., Shakibaei, R., \& Kamalinejad, M. (2010). A search for hepatoprotective activity of aqueous extract of Rhus coriaria L. against oxidative stress cytotoxicity. Food Chem. Toxicol., 48(3), 854-858. https://doi.org/10.1016/j.fct.2009.12.021

Rajendran, P., Nandakumar, N., Rengarajan, T., Palaniswami, R., Gnanadhas, E. N., Lakshminarasaiah, U., \& Nishigaki, I. (2014). Antioxidants and human diseases. Clinica. Chimica. Acta., 436, $332-347$. https://doi.org/10.1016/j.cca.2014.06.004

Reeves, P. (1997). AIN-93 Purified Diets for The Study of Trace Elements Metabolism in Rodents. In R. R. Watson (Ed.), Trace Elements in Laboratory Rodents (pp. 1-37). CRC Press. Inc. https://doi.org/ 10.1002/(SICI)1520-670X(1997)10:1\%3C37::AID-JTRA5\%3E3.0.CO;2-1

Romojaro, A., Botella, M. Á., Obón, C., \& Pretel, M. T. (2013). Nutritional and antioxidant properties of wild edible plants and their use as potential ingredients in the modern diet. Int. J. Food Sci. Nutr., 64(8), 944-952. https://doi.org/10.3109/09637486.2013.821695

Rubió, L., Motilva, M. J., \& Romero, M. P. (2013). Recent advances in biologically active compounds in herbs and spices: A review of the most effective antioxidant and anti-inflammatory active principles. Critic. Rev. Food Sci. Nutr., 53(9), 943-953. https://doi.org/10.1080/10408398.2011.574802 
Salimi, Z., Eskandary, A., Headari, R., Nejati, V., \& Kalhori, M. M. Z. (2015). Antioxidant effect of aqueous extract of sumac (Rhus coriaria L.) in the alloxan-induced diabetic rats. Indian J. Physiol. Pharmacol., 59(1), 87-93.

Scalbert, A., Johnson, I. T., \& Saltmarsh, M. (2005). Polyphenols: Antioxidants and beyond. Amer. J. Clin. Nutr., 81(1), 215S-217S. https://doi.org/10.1093/ajcn/81.1.215S

Seham, S. K., Magda, S. M., \& Madiha, M. A. (2015). Effect of some plant oils and garlic on lipids of rats fed on high cholesterol diet. International Food Res. J., 22(3), 1307-1314.

Shabbir, A. (2012). Rhus coriaria linn, a plant of medicinal, nutritional and industrial importance: A review. $J$. Anim. Plant. Sci., 22(2), 505-512.

Singh, R., Devi, S., \& Gollen, R. (2015). Role of free radical in atherosclerosis, diabetes and dyslipidaemia: Larger-than-life. Diabetes Metab. Res. Rev., 31(2), 113-126. https://doi.org/10.1002/dmrr.2558

Tawaha, K., Alali, F. Q., Gharaibeh, M., Mohammad, M., \& El-Elimat, T. (2007). Antioxidant activity and total phenolic content of selected Jordanian plant species. Food Chem, 104(4), 1372-1378. https://doi.org/ 10.1016/j.foodchem.2007.01.064

Viljoen, A. M., Petkar, S., Van Vuuren, S. F., Figueiredo, A. C., Pedro, L. G., \& Barroso, J. G. (2006). The Chemo-Geographical Variation in Essential Oil Composition and the Antimicrobial Properties of Wild Mint-Mentha longifolia subsp. polyadena (Lamiaceae) in Southern Africa. J. Essential Oil Res., 18, 60-65.

Viuda-Martos, M., El Gendy, A. E. N. G., Sendra, E., Fernandez-Lopez, J., Abd El Razik, K. A., Omer, E. A., \& Pérez-Alvarez, J. A. (2010). Chemical composition and antioxidant and anti-Listeria activities of essential oils obtained from some Egyptian plants. J. Agricul. Food Chem., 58(16), 9063-9070. https://doi.org/ $10.1021 / \mathrm{jf} 101620 \mathrm{c}$

Volf, I., Ignat, I., Neamtu, M., \& Popa, V. I. (2014). Thermal stability, antioxidant activity, and photo-oxidation of natural polyphenols. Chem. Pap., 68(1), 121-129. https://doi.org/10.2478/s11696-013-0417-6

Wang, S., Moustaid-Moussa, N., Chen, L., Mo, H., Shastri, A., Su, R., \& Shen, C. L. (2014). Novel insights of dietary polyphenols and obesity. J. Nutr. Biochem., 25(1), 1-18. https://doi.org/10.1016/j.jnutbio. 2013.09.001

Wazaify, M., Alawwa, I., Yasein, N., Al-Saleh, A., \& Afifi, F. U. (2013). Complementary and alternative medicine (CAM) use among Jordanian patients with chronic diseases. Complement. Therap. Clin. Practice., 19(3), 153-15. https://doi.org/10.1016/j.ctcp.2013.03.001

\section{Copyrights}

Copyright for this article is retained by the author(s), with first publication rights granted to the journal.

This is an open-access article distributed under the terms and conditions of the Creative Commons Attribution license (http://creativecommons.org/licenses/by/4.0/). 